\title{
Implementation of the tangential clamp in the instrumental-technological equipment with application of the clamping collets
}

\author{
Yu. N. Kuznetsov • F. El-Dahabi \\ Igor Sikorsky Kyiv Polytechnic Institute, Kyiv, Ukraine
}

Received: 31 March 2020 / Accepted: 25 May 2020

\begin{abstract}
Creation of new developing technical systems require further improvement of their subsystems. Currently, the search for new solutions is not possible without an interdisciplinary approach and the use of the latest scientific achievements in various fields, combined in the form of NBIKSE technologies (nano-bio-info-cogno-socio-eco) and using artificial intelligence, and it is necessary to apply genetic morphological approach to solve the problem of simultaneous multi-place clamping of rotating objects with the application of tangential force. In the direction of the development of previously performed works, it is proposed to add to the wellknown genetic classification of a single clamp (axial and radial principles with genetic codes F1 (Fa1, Fr1, Ft1) - F2 (Fa2, Fr2); $M 1(\mathrm{Ma1}, \mathrm{Mr} 1, \mathrm{Mt1})-\mathrm{F2}(\mathrm{Fa} 2, \mathrm{Fr} 2)$ the tangential principle of single and multiple clamping with the application of force at the output of the power flow, offset from the axis of rotation by a radius $R$.

Keywords: tangential clamp, collet chuck, genetic synthesis, material point
\end{abstract}

\section{Introduction}

The creation of new developing technical systems, which include machine tools and robotic systems, require further improvement of their subsystems.

Currently, the search for new solutions is not possible without an interdisciplinary approach and the use of the latest scientific achievements in various fields, combined in the form of NBICSE technologies (nano-bio-info-cognosocio-eco) and using artificial intelligence [1]. The challenges of the fourth industrial revolution "INDUSTRY 4.0" are mainly focused on artificial intelligence, full automation using robots, robotic systems, means of communication, the creation of a reasonable production of a new generation with a significant reduction in time and cost of manufacturing products $[3,4]$.

At the same time, machine tooling equipment is of great importance [8], expanding the technological capabilities of automated equipment and increasing its technical and economic indicators. In recent years, using a systematic evolutionary, genetic and genetic-morphological approach $[2,8,10]$ fundamentally new clamping mechanisms and devices, the use of which allowed solving problems: saving metal; increase processing accuracy; transition to the processing of cheap non-calibrated rolled products - hot rolled bars and tubes instead of calibrated; reduction in the number of readjustments and time for readjustment.

\section{Analysis of previous studies}

According to the system-structural approach, the basis for the creation of complex systems is based on the idea of elementary the doctrine of the property of elementary structures, performing the role of a theoretical basis for the generalization and synthesis of knowledge in modern fundamental sciences [10]. In this case, the methodological basis is the principle of the existence of a limited number of elementary (generating) structures, as evidenced by research in

Yu. N. Kuznetsov

info@zmok.kiev.ua
F. El-Dahabi

dahabi@i.ua 
various fields, for example: all living organisms are formed from 24 chemical elements; all colors are made of 7 colors; all musical works are written from 7 notes; all variety of numbers consists of 10 digits; all sources of the electromagnetic field contain 6 geometric classes of surfaces. In solid mechanics, there are 7 elementary transducers [8], used in our research: lever (LV), wedge (WD), spiral (SL), plunger (PL), screw (SC), gear (GR), spring (SR).

Thanks to the principles of self-organization and the genetic principle "from simple to complex" a new view of the material point is proposed as a carrier of genetic information when creating technical systems such as "object" and "process" [6].

This material point at the genetic level is conditionally called a mechanical gene and carries information about translational and rotational movements, loads and their directions The material point can be motionless, as information about static technical systems (structures, supporting systems of technological equipment).

The set of material points form a material body, the state of equilibrium or movement of which depends on the nature of the interaction with other bodies, that is, on the pressures, pulls or repulsions that the material body experiences as a result of these interactions. Using genetic algorithms and operators, hereditary information is transmitted in a number of generations (laws of mechanics, theoretical mechanics, theory of machines and mechanisms, resistance of materials, details of machines, etc.) [10-15]. By analogy with the electromagnetic field [10] in mechanics we can talk about the force field, which can serve as the initial structure containing an ordered set of mechanical genes with a given spatial sequence of their placement (distribution) within the boundaries of a geometrized topological space (surface).

According to Flynn's systematic [5, 6], 4 methods of transmitting and transmitting information are used (Fig. 1).

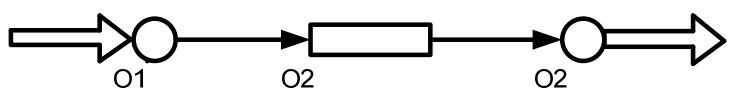

a)

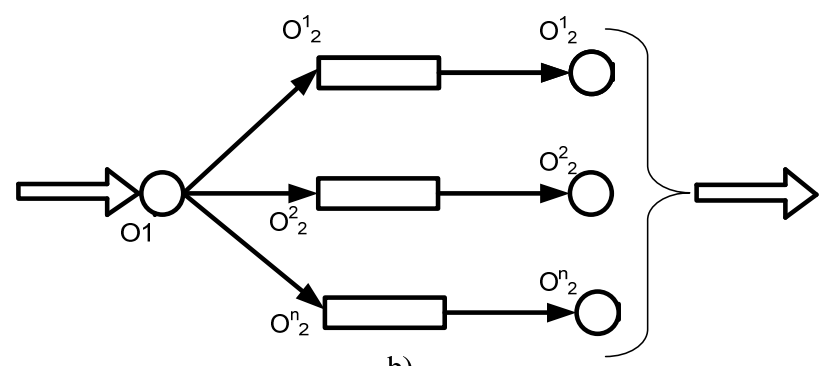

b)
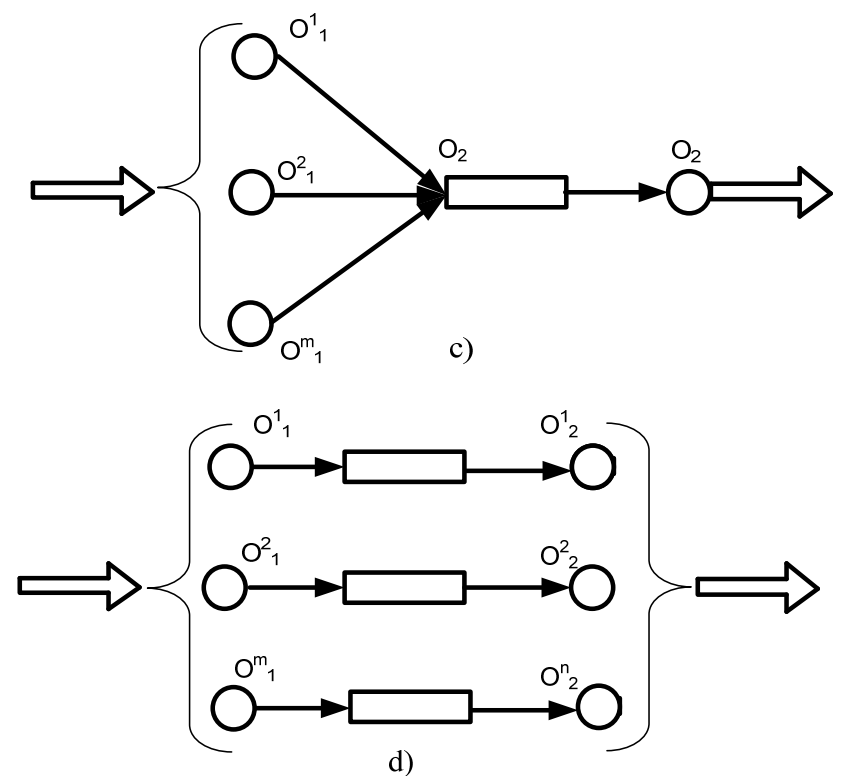

Fig. 1. Options for the transfer and transformation of information in streams using a material point as a mechanical gene: $a$ ) from one point to another; $b$ ) from one point to several; $c$ ) from several points to one; $d$ ) from several points to several

\section{Results of Real Research}

The application of the genetic-morphological approach [8] was oriented towards the clamping of one axisymmetric rotating object with access to the radial and axial clamping principles, which limited the field of search for new solutions. However, the question of simultaneous multi-place clamping of rotating objects fell out of sight, which is widely used in machine tools for processing non-rotating workpieces. One of the first examples of the tangential clamping principle was the invention of the "Collet Chuck" [9], in which holes were made at the end of the collet lips, the axes of which lie in the planes passing through the collet axis and through the middle of the slots forming the petals.

The solution to the problem of simultaneous multi-place clamping of rotating objects with the application of a tangential force offset from the axis of rotation determined the relevance and purpose of these studies. In the direction of the development of previously performed works [5], it is proposed to add to the well-known genetic classification of a single clamp [6] (axial and radial principles with genetic codes $\mathrm{F}_{1}\left(\mathrm{~F}_{\mathrm{a} 1}, \mathrm{~F}_{\mathrm{r} 1}, \mathrm{~F}_{\mathrm{t} 1}\right)-\mathrm{F}_{2}\left(\mathrm{~F}_{\mathrm{a} 2}, \mathrm{~F}_{\mathrm{r} 2}\right) ; \mathrm{M}_{1}\left(\mathrm{M}_{\mathrm{a} 1}, \mathrm{M}_{\mathrm{r} 1}, \mathrm{M}_{\mathrm{t} 1}\right)$ $-\mathrm{F}_{2}\left(\mathrm{~F}_{\mathrm{a} 2}, \mathrm{~F}_{\mathrm{r} 2}\right)$ the tangential principle of single and multi-place clamping with the application of force at the output of the power flow, offset from the axis of rotation by a radius $\mathrm{R}$. At the same time, it appears in addition to the well-known genetic classification [7, 8], which has 48 power flows, another 24 with genetic codes $\mathrm{F}_{1}\left(\mathrm{~F}_{\mathrm{a} 1}, \mathrm{~F}_{\mathrm{rl}}, \mathrm{F}_{\mathrm{t} 1}\right)-\mathrm{F}_{2}\left(\mathrm{~F}_{\mathrm{t} 2}\right) ; \mathrm{M}_{1}\left(\mathrm{M}_{\mathrm{a} 1}, \mathrm{M}_{\mathrm{r} 1}\right.$, $\left.\mathrm{M}_{\mathrm{t} 1}\right)-\mathrm{F}_{2}\left(\mathrm{~F}_{\mathrm{t} 2}\right)$. In these studies, the code Fa1 - Ft2 with a wedge transducer (displacement, force, energy) and orientation on the collet clamp (Fig. 2) was selected. 


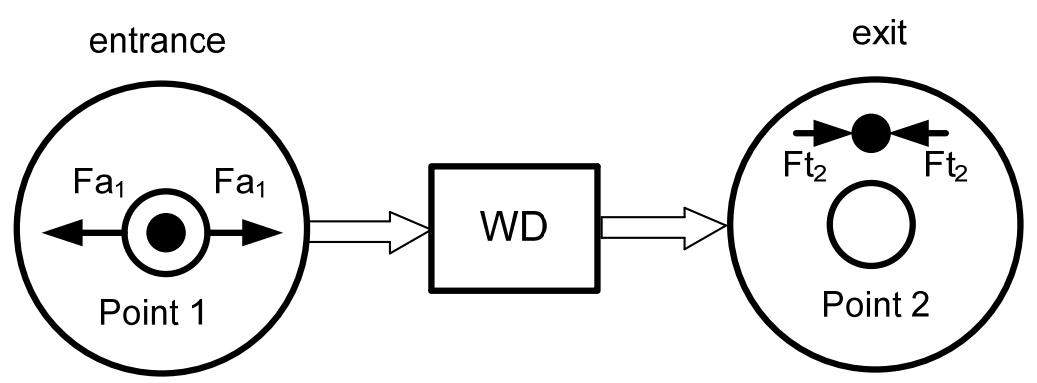

Fig. 2. Diagram of the transfer of genetic information with a wedge transducer from the input (point 1) to the output (point 2) in a tooling with tangential clamp

Earlier, based on the analysis of evolutionary development and the long-term use of collet chucks in machine tools in various countries of the world and the process of their mutation $[1,4,7,10]$, the collet chuck with a pulling collet was selected as the most common (Fig. 3, table 1 )

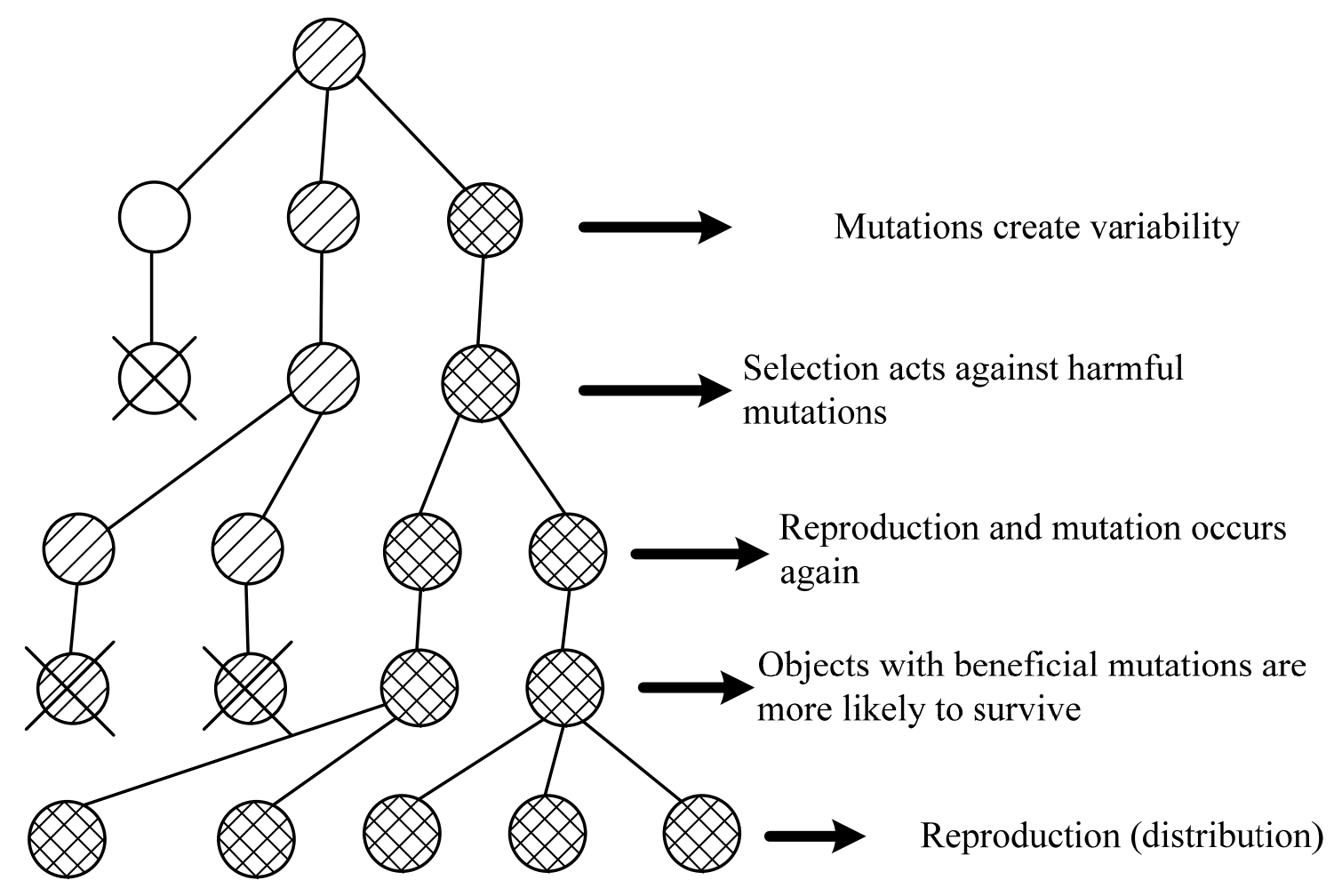

Fig. 3. Natural selection of single-clamp collet chucks for single-clamping lathes due to mutations with symbols:

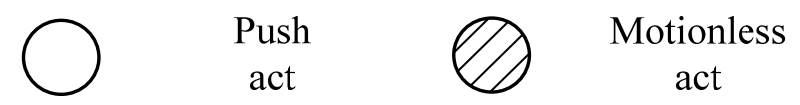

Addictive

act

As an example, for the case of the input axial force Fal and the output tangential force $\mathrm{Ft}_{2}$, Fig. 2 shows the synthesized instrumental collet mandrel (end mill) with the simultaneous clamping of four cutting inserts. In multilevel genetic modeling and description, the following was taken into account [8, 10]: each level of the structural hierarchy preserves hereditary (genetic) information of a previous level; the structure of an object of an arbitrary level is formed on the basis of structures of previous levels (the higher the level of the hierarchy, the higher the complexity of the object); each object of an arbitrary hierarchy level is represented by a genetic code or structural formula. 
Table 1. Examples of description (modeling) and application of tooling with the tangential principle of a collet clamp

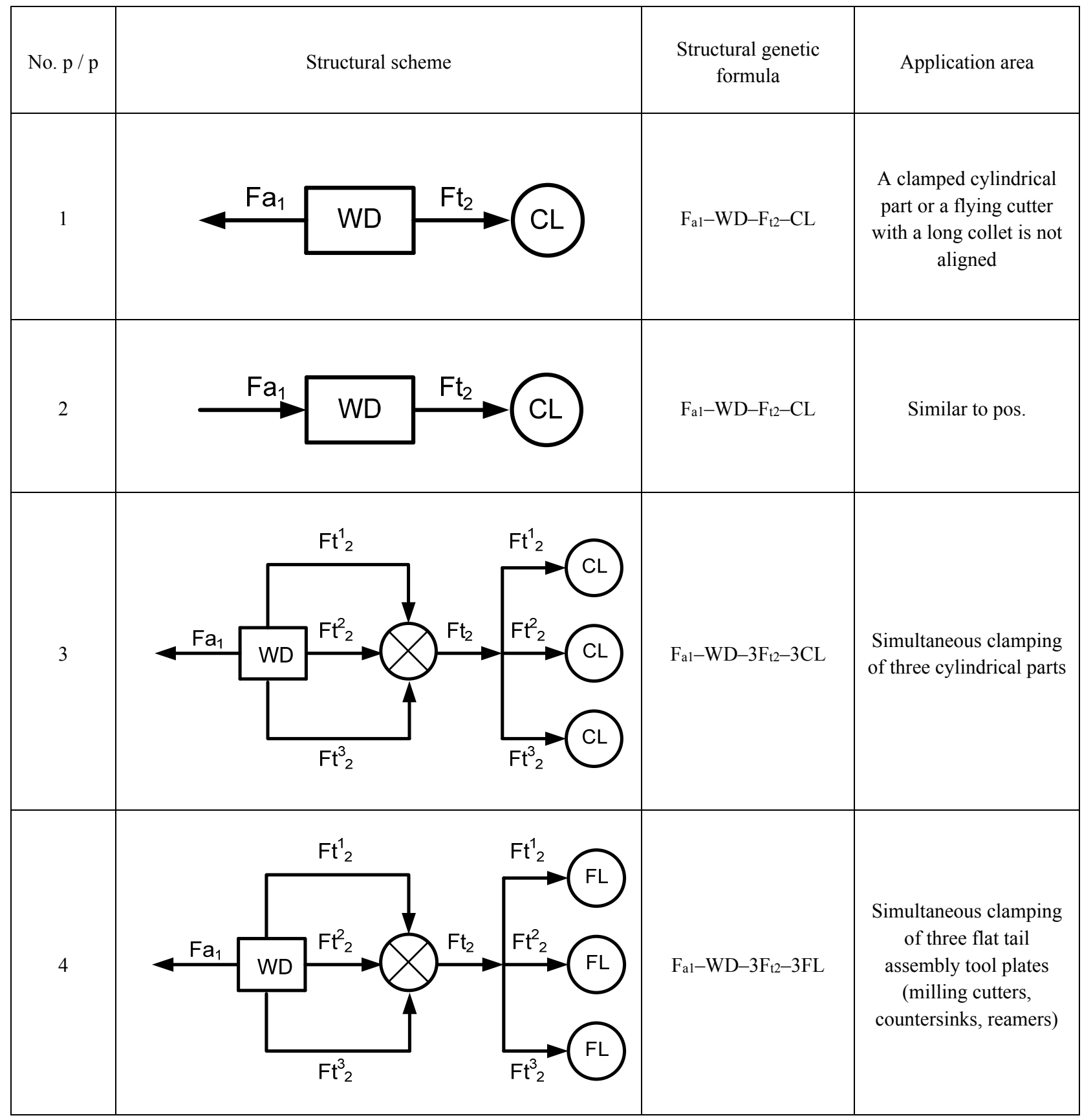

The description (modeling) with the complexity of the structure and the buildup of genetic information is presented in the form of structural genetic formulas at the following levels:

- genetic, $\mathrm{F}_{\mathrm{a} 1}$

- chromosomal, $\mathrm{F}_{\mathrm{a} 1}-\mathrm{F}_{\mathrm{t} 2}$;

- object, $\mathrm{F}_{\mathrm{a} 1}-\mathrm{K}_{\mathrm{R} !} \mathrm{F}_{\mathrm{t} 2}$;

- population, $\mathrm{F}_{\mathrm{a} 1}-\mathrm{WD}-\mathrm{K}_{\mathrm{R}} \mathrm{F}_{\mathrm{t} 2}$;

- specific, $\mathrm{F}_{\mathrm{a} 1}-\mathrm{WD}-\mathrm{K}_{\mathrm{R}} \mathrm{F}_{\mathrm{t} 2}-\mathrm{K}_{\mathrm{R} 2} \mathrm{CL}$ (cylindrical shape of the clamping object);

$\mathrm{F}_{\mathrm{a} 1}-\mathrm{WD}-\mathrm{K}_{\mathrm{R} !} \mathrm{F}_{\mathrm{t} 2}-\mathrm{K}_{\mathrm{R} 2} \mathrm{FL}$ (flat shape of the clamping object); ;

The latest model, taking into account the universal genetic replication operator

$\mathrm{K}_{\mathrm{R}}=\mathrm{K}_{\mathrm{R} !}=\mathrm{K}_{\mathrm{R} 2}[7,8,10]$ is shown in Fig. 4 for various circuits of tooling equipment. 

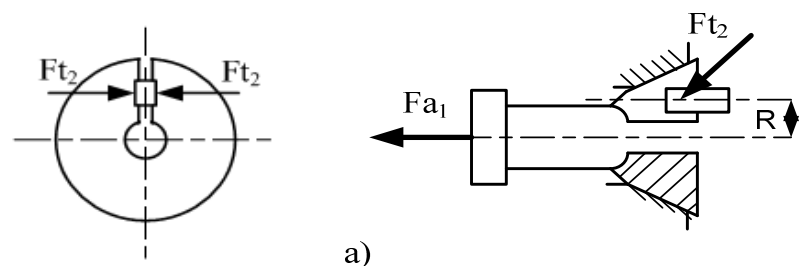

a)
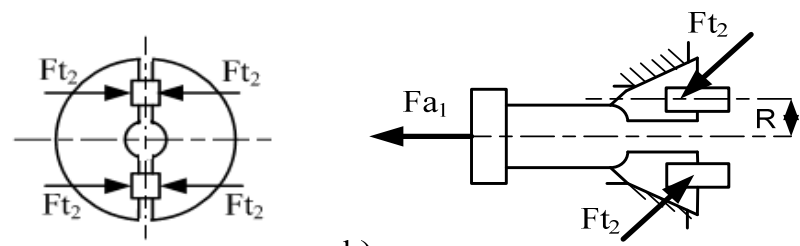

b)
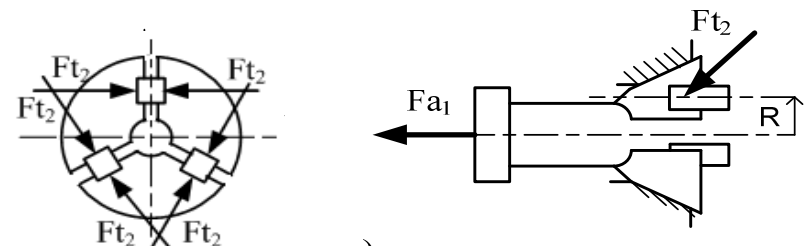

c)
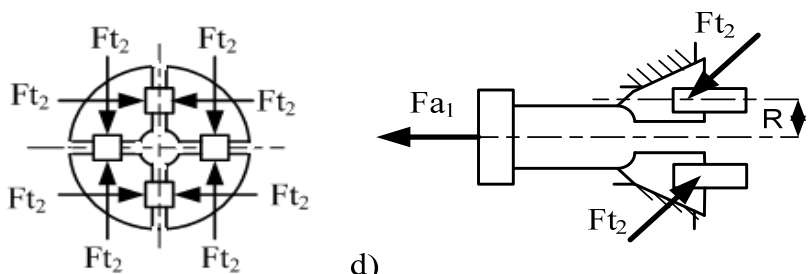

d)

Fig. 4. Schemes of tooling with a collet clamp and genetic formulas at a species level: a) $\mathrm{F}_{\mathrm{a} 1}-\mathrm{WD}-\mathrm{F}_{\mathrm{t} 2}-\mathrm{FL}$; b) $\mathrm{F}_{\mathrm{a} 1}-\mathrm{WD}-2 \mathrm{~F}_{\mathrm{t} 2}-2 \mathrm{FL} ;$ c) $\mathrm{F}_{\mathrm{a} 1}-\mathrm{WD}-3 \mathrm{~F}_{\mathrm{t} 2}-3 \mathrm{FL} ;$ d) $\mathrm{F}_{\mathrm{a} 1}-\mathrm{WD}-4 \mathrm{~F}_{\mathrm{t} 2}-4 \mathrm{FL}$

With an even factor - a replication coefficient multiple of 2, the genetic formulas can change form (Fig. 5), and, therefore, the design changes.

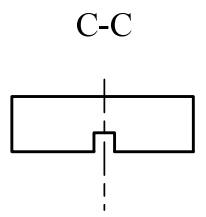

E-E
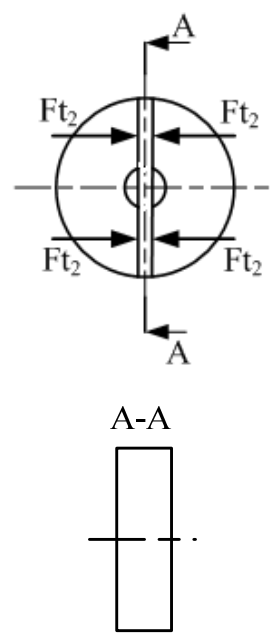

$a$

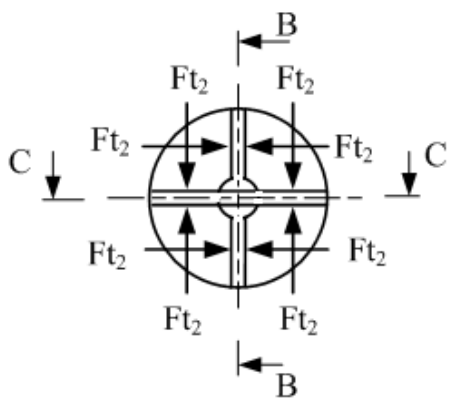

B-B

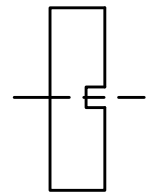

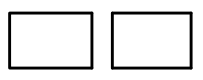

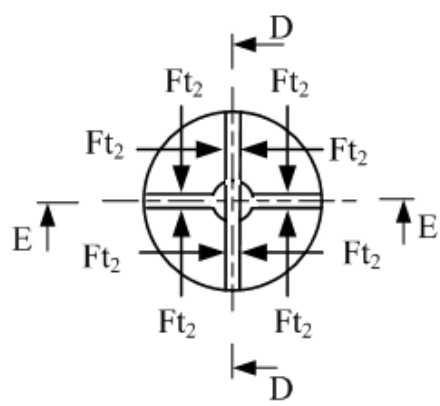

D-D

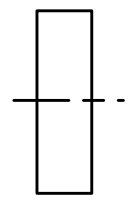

Fig. 5. Schemes of tooling with an input Fal (see Fig. 4), an even number of clamping jaw lips and genetic formulas at the species level: a) $\left.\left.\mathrm{F}_{\mathrm{a} 1}-\mathrm{WD}-2 \mathrm{~F}_{\mathrm{t} 2}-\mathrm{FL} ; b\right) \mathrm{F}_{\mathrm{a} 1}-\mathrm{WD}-4 \mathrm{~F}_{\mathrm{t} 2}-2 \mathrm{FL} ; c\right) \mathrm{F}_{\mathrm{a} 1}-\mathrm{WD}-4 \mathrm{~F}_{\mathrm{t} 2}-3 \mathrm{FL}$ 
An example of a synthesized end mill with a collet clamp of cutting carbide inserts, corresponding at the species level to the genetic code Fa1 - WD $-4 \mathrm{Ft} 2-4 \mathrm{FL}$, is shown in Fig. 6. According to it, technical documentation is developed, a prototype for laboratory and production tests is made.

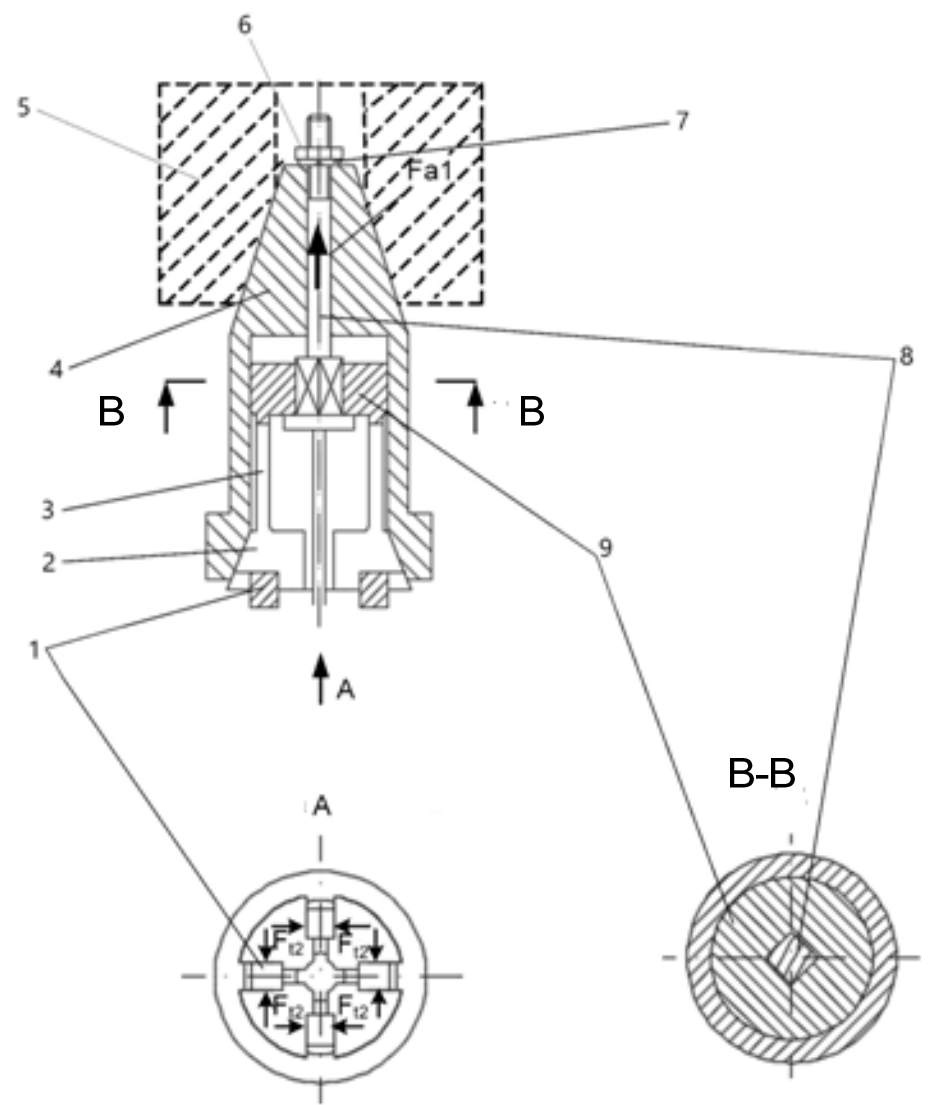

Fig. 6. Face mill with tangential clamp: 1 - cutting insert; 2 - sponge; 3 - petal; 4 - body with a tapered shank; 5 - spindle; 6 - nut; 7 - lock washer; 8 - special screw; 9 - grip clamping four-petal

\section{Conclusion}

The use of the tangential clamping principle opens up new possibilities for the synthesis of rotating machine tool tools with the simultaneous fastening of several products.

\section{References}

1. Automation of search design (artificial intelligence in machine design) / A.I. Polovinkin, N.K. Bobkov, T. Ya. Bush and others.; under the editorship of A.I. Polovinkin. - M.: Radio and communications. $-1981 .-344$ p.

2. Volokhonsky A.G. Genetic code and symmetry // Symmetry in nature. - L.: $-1971 .-75$ p.

3. Kuznetsov Yu. N. Challenges of the fourth industrial revolution "Industry 4.0" to the scientists of Ukraine // Bulletin of KNTU. - 2017. - Vol. 61, No. 2. - P. 67-75.

4. Kuznetsov Yu.M. Stages of the evolution of creative thinking with elements of artificial intelligence on the example of the synthesis of collet cartridges // Intercollegiate Collection "Scientific Notes", Lutsk, - 2019. - No. 67. - P. 70-81.

5. Kuznetsov Yu. N., El-Dahabi F.W. The development of the genetic-morphological approach in the synthesis of machine tooling // Transactions of the International Scientific Conference UNITECH "18, vol. 2, Gabrovo, - 2018. - P. $183-189$.

6. Kuznetsov Yu. N. A new look at the material point as a carrier of genetic information when creating technical systems // Materials of the International scientific-practical conference "Fundamentals of Mechanics", Novokuznetsk: SIC MS. - 2016. No. 1. - P. 26-40.

7. Kuznetsov Yu.M., Dahabi F.W, Hamuyela J.A. Guerra. Structural scheme synthesis of clamping chucks гsing гniversal геnetic operators // Scientific journal "Fundamentalis scientiam", (Madrid, Spain). - 2017. Vol. 12, No. 2. - P. $43-49$.

8. Hamujela J.A. Gerra Genetic and morphological synthesis of clamping chucks: monograph / J.A. Gerra Hamuyela, Yu.N. Kuznetsov, T.O. Hamuyela; under the editorship of Yu.N. Kuznetsov. - Lutsk: Vezha-Druk, - 2017. - 328 p.

9. Collet chuck. Authorship certificate of the USSR No. 292734, IPC B23B 31/00, author V.I. Gribachov, application No. $1281181 / 25$ of 11.11 .1968 .

10. Shinkarenko V.F., Fundamentals of the theory of evolution of electromechanical systems. - K .: Scientific Thought, -2002 . -288 p.

11. Kunjur, A., Krishnamurty, S. "Genetic Algorithms in Mechanical Synthesis", Journal of Applied Mechanisms and Robotics, - 1997. - Vol. 4, No. 2. - P. 18-24. 
12. Omer A. Shpil "Genetic algorithms in synthesis of path generator four-bar mechanism with maximum mechanical advantage". ASM '07: The 16th IASTED International Conference on Applied Simulation and Modeling August 2007 P. $154-161$.

13. Cabrera, J.A., Simon A., Prado M., "Optimal synthesis of mechanisms with genetic algorithms" Mechanism and Machine Theory 37. - 2002. - P. 1165-1177.

14. Lee Kunwu. CAD Basics (CAD / CAM / CAE) Per. from English - St. Petersburg: Peter, - 2004. - 580 p. (Ch. 9, p. 9.5. Genetic algorithms). P. 284-291.

15. https://yandex.ua/images/search?img_url=http:www.komane.ru/nu

\title{
Реализация тангенциального зажима в инструментально-технологической оснастке с применением цанговых патронов
}

\author{
Ю. Н. Кузнецов, Ф. В. Эль-Дахаби
}

Аннотацыя: Создание новых развивающихся технических систем требует дальнейшего усовершенствования их подсистем. В настоящее время поиск новых решений не возможен без междисииплинарного подхода и использования последних научных достижений в различных областях знаний, обединенных в виде НБИКСЭ (нано-био-инфо-когно-соичоэко) - технологий. Предложено применять генетико - морфологический подход для решения прблемы обеспечения одновременного одним движением многоместного зажима вращающихся объектовс использованием тангенцильной силь. Ключевые слова: тагенциальный зажим, цанговый патрон, генетический синтез, материальная точка

\section{Реалізація тангенціального затиску в інструментально-технологічному оснащенні із застосуванням цангових патронів}

\author{
Ю. М. Кузнєцов, Ф. В. Ель-Дахабі
}

Анотація: Створення нових технічних систем, Що розвиваються, потребує подальшого удосконалення їх підсистем. На сьогодні пошук нових рішень не можливий без міждисциплінарного підходу і використання останніх наукових досягнень 8 різних областях знань, які об'єднані у вигляді НБІКСЕ (нано-біо-інфо-когно-соціо-еко)-технологій $і$ використовують штучний інтелект. Запропоновано використовувати генетико - морфологічний підхід для рішення проблеми забезпечення одночасного одним рухом багатомісцевого затиску об” "ктів, щуо обертаються, з застосуванням тангенціальної сили. Ключові слова: тангенціальний затиск, цанговий патрон, генетичний синтез, матеріальна точка

\section{References}

1. Polovinkin A.I., Bobkov N.K., Bush T. Ya. and dr. (1981), Automation of search design (artificial intelligence in machine design), in Polovinkin, A.I. (ed.), monograph, Radio and communications, Moscow, Russia.

2. Volokhonsky, A.G. (1971), Genetic code and symmetry, Symmetry in nature, Leningrad, Russia.

3. Kuznetsov, Yu.N. (2017), Challenges of the fourth industrial revolution "Industry 4.0" to the scientists of Ukraine, Bulletin of KNTU, vol. 61, no. 2. pp. 67-75.

4. Kuznetsov, Yu.M. (2019), "Stages of the evolution of creative thinking with elements of artificial intelligence on the example of the synthesis of collet cartridges", Intercollegiate Collection "Scientific Notes", Lutsk, no. 67, pp. 70-81.

5. Kuznetsov, Yu.N. and El-Dahabi F.W. (2018), "The development of the genetic-morphological approach in the synthesis of machine tooling", Transactions of the International Scientific Conference UNITECH "18, Gabrovo, vol. 2, pp. 183-189.

6. Kuznetsov, Yu.N. (2016), "A new look at the material point as a carrier of genetic information when creating technical systems", Materials of the International scientific-practical conference "Fundamentals of Mechanics", SIC MS, Novokuznetsk, no. 1, pp. 26-40.

7. Kuznetsov Yu.M., Dahabi F.W. and Hamuyela J.A. Guerra (2017), "Structural scheme synthesis of clamping chucks rsing гniversal геnetic operators", Scientific journal "Fundamentalis scientiam”, Madrid, Spain, vol. 12, no. 2, pp. 43-49.

8. Hamujela, J.A., Gerra Kuznetsov, Yu.N. and Hamuyela, T.O. (2017), Genetic and morphological synthesis of clamping chucks, monograph, in Kuznetsov, Yu.N. (ed.), Vezha-Druk, Lutsk, Ukraine.

9. Gribachov, V.I. (1968), Collet chuck. IPC B23B 31/00, application no. 1281181/25 of 11.11. 1968, Authorship certificate of the USSR No. 292734.

10. Shinkarenko, V.F. (2002), Fundamentals of the theory of evolution of electromechanical systems, Scientific Thought, Kyiv, Ukraine.

11. Kunjur, A. and Krishnamurty, S. (1997), “Genetic Algorithms in Mechanical Synthesis”, Journal of Applied Mechanisms and Robotics, vol. 4, no. 2, pp. 18-24.

12. Omer, A. Shpil (2007), "Genetic algorithms in synthesis of path generator four-bar mechanism with maximum mechanical advantage", ASM '07: The 16th IASTED International Conference on Applied Simulation and Modeling, August, pp. 154-161.

13. Cabrera, J.A., Simon, A. and Prado, M. (2002), "Optimal synthesis of mechanisms with genetic algorithms" Mechanism and Machine Theory, no. 37, pp. 1165-1177.

14. Lee Kunwu (2004), CAD Basics (CAD / CAM / CAE) Per. from English, (Ch. 9, p. 9.5. Genetic algorithms, St. Petersburg, Peter, Russia. pp. 284-291.

15. https://yandex.ua/images/search?img_url=http:www.komane.ru/nu 